\title{
Sintesis dan Karakterisasi Nanopartikel Perak-Tricalcium Phosphate (TCP) dengan Bantuan Ekstrak Daun Alpukat (Percea americana)
}

\section{Synthesis and Characterization Silver-Tricalcium Phosphate (TCP) Nanoparticle using Avocado Leaf Extract (Percea americana)}

\author{
Yessi Rahmayani, Zulhadjri, Syukri Arief* \\ ${ }^{1}$ Jurusan Kimia, Fakultas Matematika dan Ilmu Pengetahuan Alam, Universitas Andalas \\ Limau Manis, Padang, Sumatera Barat Kode Pos 25163 Po. Box 143 \\ *Corresponding author: syukriarief@gmail.com
}

Receive: July 2018; Revision: October 2018; Accepted: April 2019; Available online: May 2019

\begin{abstract}
Abstrak
Sintesis nanopartikel perak-TCP telah dilakukan pada penelitian ini. Nanopartikel perak dibuat dengan mereduksi larutan perak nitrat dengan menggunakan ekstrak daun alpukat sebagai bioreduktor. Tricalsium Phosphate (TCP) dicelupkan kedalam nanopartikel perak membentuk komposit perak-tricalcium phosphate. Hasil analisis UV-Vis menunjukkan pembentukan puncak serapan nanopartikel perak pada panjang 445-446 nm, yakni puncak yang khas dari nanopartikel perak yang disebabkan oleh adanya fenomena Surface Plasmon Resonance (SPR). Penelitian ini menghasilkan perak-TCP dengan ukuran nanopartikel. Sesuai hasil X-Ray Diffraction (XRD) yang menunjukkan bahwa ukuran kristal TCP adalah $64 \mathrm{~nm}$ dan ukuran Kristal perak dalam komposit adalah $46 \mathrm{~nm}$. Hasil Scanning Electron Microscopy (SEM) menunjukan partikel perak terdistribusi dipermukaan partikel TCP.
\end{abstract}

Kata Kunci: Komposit perak-TCP, nanopartikel perak, Percea americana, tricalcium phosphate.

\begin{abstract}
The silver-TCP nanoparticle synthesis was carried out in this study. Silver nanoparticles are made by reducing silver nitrate solution using avocado leaf extract as a bioreactor. Tricalcium Phosphate (TCP) is dipped into silver nanoparticles to form a silver-tricalcium phosphate composite. The UV-Vis analysis shows the formation of silver nanoparticle absorption peaks at a length of $445-446 \mathrm{~nm}$, which is a typical peak of silver nanoparticles caused by the Surface Plasmon Resonance (SPR) phenomenon. X-Ray Diffraction (XRD) shows that the TCP crystal size is $64 \mathrm{~nm}$ and the size of the Silver Crystal in the composite is $46 \mathrm{~nm}$. The results of Scanning Electron Microscopy (SEM) show silver particles distributed on the surface of TCP particles
\end{abstract}

Keywords: Percea americana, silver-TCP composite, silver nanoparticle, tricalcium phosphate.

DOI: $10.15408 / j k v \cdot v 5 i 1.8652$

\section{PENDAHULUAN}

Dalam dua dekade terakhir ini, penelitian dalam bidang nanopartikel menjadi sangat popular. Penelitian dalam bidang nanopartikel terutama nanopartikel logam semakin menarik perhatian karena sifat yang unik seperti sifat katalis (Singh et al., 2008), sifat optik (Kelly et al., 2003) dan aplikasi biologi (Navindra et al., 2014). Salah satu nanopartikel logam yang telah banyak disintesis adalah nanopartikel perak. Akhir- akhir ini dikembangkan teknik sintesis nanopartikel logam yang lebih sederhana, efektif dalam pembiayaan, efisien dan ramah lingkungan yaitu salah satunya dengan menggunakan ekstrak tanaman. Ekstrak tanaman ini mengandung alkaloid, tannin, steroid, fenolik, saponin dan flavonoid, yang pada dasarnya senyawa-senyawa ini dapat mereduksi ion perak menjadi atom perak dan membentuk nanopartikel perak (Sangiliyandi et al., 2014). Beberapa jenis tanaman yang 
telah dipublikasikan sebagai reagen untuk sintesis diantaranya adalah Tribulus terretris (Gopinath, et.al 2012), Foeniculum vulgare (Shital,2011), Pinus eldarica Bark (Siavash dan Behzad, 2013), Uncaria gambir Roxb (Jami, 2017), Percea americana (Vinay et al., 2017).

Menurut Kumar et al., (2016), daun alpukat memiliki aktivitas antioksidan yang tinggi dibandingkan dengan bagian lain dari tumbuhan ini (kulit buah, daging buah dan lemaknya). Dari hasil spektrum FTIR pada daun alpukat muncul puncak kuat pada 3300$3284 \mathrm{~cm}^{-1}$ dan 1671-1611 $\mathrm{cm}^{-1}$ yang menandakan senyawa polifenol (flavonoid).

Penelitian tentang sintesis komposit perak-TCP belum banyak dilaporkan. Ozkan, et.al (2015) melaporkan dengan metoda presipitasi dan sintering, menunjukan penambahan perak kedalam kalsium pospat dapat menstabilkan fasa $\beta$-TCP setelah sintering dan pendistribusian yang homogen. $\beta$-TCP menunjukan kelarutan $\mathrm{Ag}$ yang lebih baik dibandingkan HAP. Dengan wet chemical synthesis dilaporkan adanya tren yang menarik dalam hal stabilitas komposisi tergantung pada suhu sintering yang dipilih (Brajendra dan Samayendra, 2015). Penggunaan teknik adsorpsi melibatkan pencelupan (immersed method) TCP dalam koloid perak belum dilaporkan. Proses yang sederhana melibatkan pencelupan serbuk TCP dalam koloid AgNPs menjadi sangat menarik karena tidak membutuhkan peralatan yang rumit dan membutuhkan reagen yang murah.

Sintesis nanopartikel perak-HAP dengan menggunakan ektsrak gambir telah dilaporkan. Menurut Jami, (2017) penggunaan ekstrak gambir sebagai pereduksi efektif membentuk nanopartikel perak, kemudian HAP dicelupkan kedalam koloid perak tersebut. TCP merupakan fasa kedua dari HAP. Untuk itu peneliti melakukan sintesis nanopartikel perak-TCP dengan bantuan ekstrak daun alpukat sebagai pereduksi. Pada penelitian ini, sintesis nanopartikel perak dengan TCP menggunakan metoda sederhana. Serbuk TCP disintesis melalui metoda basah yaitu metoda pengendapan dengan menggunakan prekusor kalsium nitrat sebagai sumber kalsium dan diamonium hidrogen pospat sebagai sumber pospat serta larutan ammonium hidroksida sebagai pengatur $\mathrm{pH}$ larutan. Setelah itu serbuk yang diperoleh dipanaskan sampai suhu $1000{ }^{\circ} \mathrm{C}$. Proses pengendapan ini dipilih karena mudah dilakukan dan peralatan yang digunakan sederhana serta kristal diperoleh dalam ukuran nano. Selanjutnya untuk memperoleh komposit Ag-TCP dilakukan dengan teknik adsoprsi dimana serbuk TCP yang dihasilkan dicelupkan kedalam koloid nanopartikel perak yang diperoleh dari mereduksi larutan perak nitrat dengan ekstrak daun alpukat (Persea americana) sebagai pereduksi alami. Metoda ini dilakukan karena peralatan yang digunakan sederhana, proses mudah dan pereduksi yang digunakan alami sehingga lebih ramah lingkungan.

\section{METODE PENELITIAN}

Sintesis Tricalsium phosphate (TCP) menggunakan bahan $\mathrm{Ca}\left(\mathrm{NO}_{3}\right)_{2} \cdot 4 \mathrm{H}_{2} \mathrm{O}$ sebagai sumber $\mathrm{Ca},\left(\mathrm{NH}_{4}\right)_{2} \mathrm{HPO}_{4}$ sebagai sumber fosfor dan $\mathrm{NH}_{4} \mathrm{OH}$ untuk pengaturan $\mathrm{pH} 8-9$, aquades sebagai pelarut. Sintesis nanopartikel perak menggunakan bahan $\mathrm{AgNO}_{3}$ (Brataco, 99.98\%), daun alpukat segar sebagai bioreduktor dan aquades sebagai pelarut.

Dalam penelitian ini menggunakan alat-alat kaca seperti gelas piala, pipet tetes, corong, Erlenmeyer, labu ukur, Oven, timbangan analitik, kertas $\mathrm{pH}$, furnace, hot plate stirrer, magnetic bar, kertas saring dan untuk karakterisasi menggunakan Spektrometer UV-Vis (AnalitikJena Specord), XRD (Philips X'pert Powder PAN Alytical), SEM (Hitachi S-3400N).

\section{Sintesis TCP}

Pembuatan TCP dilakukan dengan metoda pengendapan. Prekusor yang digunakan adalah kalsium nitrat, $\mathrm{Ca}\left(\mathrm{NO}_{3}\right)_{2} \cdot 4 \mathrm{H}_{2} \mathrm{O}$ sebagai prekusor kalsium dan diamonium hidrogen pospat, $\left(\mathrm{NH}_{4}\right)_{2} \mathrm{HPO}_{4}$ sebagai prekusor fosfor. Rasio molar $\mathrm{Ca} / \mathrm{P}$ dari pereaksi adalah 1.5, sesuai dengan penelitian sebelumnya (Chaair et al., 2017). Langkah pertama adalah menyiapkan kedua reagen yang akan direaksikan. Kalsium nitrat dilarutkan dengan akuades lalu distirer kuat selama lebih kurang 30 menit dan kemudian secara perlahan-perlahan ditambahkan diamonium hidrogen pospat yang telah dilarutkan. Diamonium hidrogen pospat ditambahkan dengan menggunakan buret. Setelah bercampur, ditambahkan ammonium hidroksida sebagai pengatur $\mathrm{pH}$ 8-9. Stirer dilanjutkan selama 5 jam. Endapan yang terbentuk disaring memakai kertas saring 
Whatman No. 1 dan dicuci dengan aquades sampai netral. Kemudian dikeringkan pada suhu $100{ }^{\circ} \mathrm{C}$ selama $12-16$ jam. Padatan yang diperoleh digerus hingga membentuk bubuk. Setelahnya dilakukan proses kalsinasi pada suhu $1000{ }^{\circ} \mathrm{C}$

\section{Persiapan Ekstrak Daun Alpukat}

Daun alpukat segar dicuci 2-3 kali dengan air dan terakhir dicuci dengan aquades. Daun alpukat yang telah bersih dipotong kasar. Sebanyak 10 gram daun alpukat cincang dimasukkan kedalam gelas piala dan ditambahkan $100 \mathrm{~mL}$ aquades, diaduk pada suhu $60{ }^{\circ} \mathrm{C}$ selama 30 menit. Campuran didinginkan dan disaring dengan kertas saring Whatmann No. 1. Ekstrak daun alpukat disimpan dalam lemari pendingin.

\section{Sintesis Nanopartikel Perak}

Larutan $\mathrm{AgNO}_{3} 0.01 \mathrm{~N}$ dimasukkan kedalam gelas piala ditambahkan ekstrak daun alpukat dengan variasi perbandingan ekstrak daun alpukat dengan larutan $\mathrm{AgNO}_{3}$ adalah 1:1 dan 1:2 (v/v). Campuran ini diaduk pada suhu kamar dengan variasi waktu 0,30 menit, 1 jam, 2 jam, 3 jam, 4 jam, 5 jam dan 6 jam. Terbentuknya nanopartikel perak ditunjukan oleh pita serapan pada Spektrofotometer UVVis pada panjang gelombang 446-448 nm sesuai dengan laporan sebelumnya oleh Banerjee, et al (2014).

\section{Sintesis Nanopartikel Perak-TCP}

Untuk membuat nanopartikel perakTCP, serbuk TCP sebanyak 0.1 gram ditambahkan kedalam koloid perak yang terbentuk. Penambahan TCP dilakukan saat waktu optimum pembentukan koloid perak. Untuk campuran $\mathrm{AgNO}_{3} 0.01 \mathrm{~N}$ dan ekstrak daun alpukat 1:1, serbuk TCP dimasukkan pada waktu jam ke-3. Campuran TCP dan koloid Ag distirer selama 30 menit. Suspensi Ag-TCP yang terbentuk didiamkan untuk dilakukan proses dekantasi. Padatan yang diperoleh dipanaskan pada suhu $70{ }^{\circ} \mathrm{C}$ selama 6 jam.

Karakterisasi dilakukan pada serbuk TCP, koloid Ag dan nanopartikel Ag-TCP yang terbentuk. Analisis menggunakan spektrofotometer UV-Vis untuk mengetahui serapan dan panjang gelombang optimum pembentukan nanopartikel perak. Analisis XRD dilakukan untuk mengetahui struktur kristal, ukuran kristal dan fase kristal dari TCP dan nanopartikel Ag-TCP yang dihasilkan. Analisis SEM dilakukan untuk mengetahui morfologi permukaan partikel dan ukuran partikel dari TCP dan nanopartikel Ag-TCP yang dihasilkan.

\section{HASIL DAN PEMBAHASAN}

Sintesis nanopartikel perak telah dilakukan dengan variasi perbandingan jumlah ekstrak dan larutan perak nitrat dan variasi waktu. Gambar 1 memperlihatkan warna dari ekstrak daun alpukat dan warna koloid nanopartikel perak.

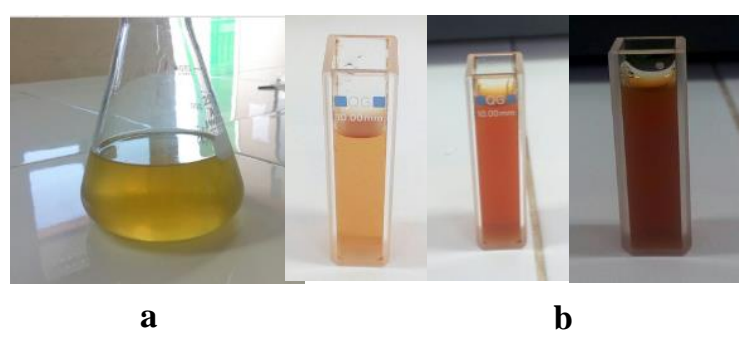

Gambar 4. (a) ekstrak daun alpukat (b) ekstrak daun $+\mathrm{AgNO}_{3} 0,01 \mathrm{~N}$

Dari penelitian yang dilakukan terjadi perubahan warna dari ekstrak setelah penambahan larutan perak nitrat menandakan koloid perak mulai terbentuk. Secara umum terbentuknya nanopartikel perak ditandai dengan perubahan warna dari kuning menjadi kecoklatan. Perubahan warna ini dimulai saat pencampuran sudah melebihi waktu 30 menit. Warna yang khas dari nanokomposit perak disebabkan karena adanya absorbansi plasmon pada permukaan perak. Warna yang dihasilkan pada setiap sampel menunjukkan adanya pengaruh dari zat pereduksi organik yang digunakan. Semakin lama waktu pencampuran, warna larutan semakin pekat. Hal ini sesuai dengan penelitian sebelumnya yang dilakukan oleh Veerasamy et al., (2011) yang menyatakan perubahan warna larutan setelah penambahan ekstrak dengan variasi waktu menandakan terbentuknya nanopartikel perak. Hal ini disebabkan oleh eksitasi getaran permukaan plasmon (Surface Plasmon Vibration) dalam nanopartikel perak.

Setelah dilakukan pengamatan terhadap perubahan warna dari nanopartikel perak, dilakukan karakterisasi dengan spektroskopi UV-Vis, untuk mengetahui absorbansi dan panjang gelombang optimum dari pembuatan nanokomposit perak. Analisis 
dengan spektroskopi UV-Vis juga berfungsi untuk menganalisis surface plasmon resonance (SPR) yang terjadi pada koloid nanopartikel perak. Surface Plasmon Resonance merupakan fenomena pergerakan awan elektron dipengaruhi oleh adanya penyinaran pada koloid nanokomposit atau disebut dengan fenomena resonansi osilasi (Junaidi et al., 2015). Menurut Banerjee et al., (2014) nanopartikel perak memiliki pita serapan pada range $446-448 \mathrm{~nm}$, sedangkan Obaid, et.al (2015) mendapatkan bahwa pita serapan UV dari SPR nanopartikel perak terdeteksi pada panjang gelombang 436-446 nm. Pita serapan nanopartikel perak yang dihasilkan dari mencampurkan ekstrak daun alpukat dan larutan perak nitrat konsentrasi $0.01 \mathrm{~N}$ dengan perbandingan volume 1:1 dan 1:2 dapat diamati pada gambar 2 .

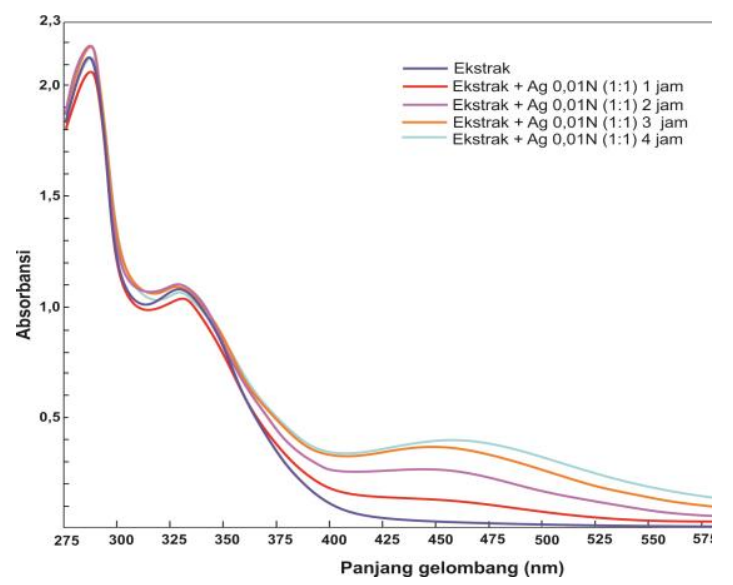

(a)

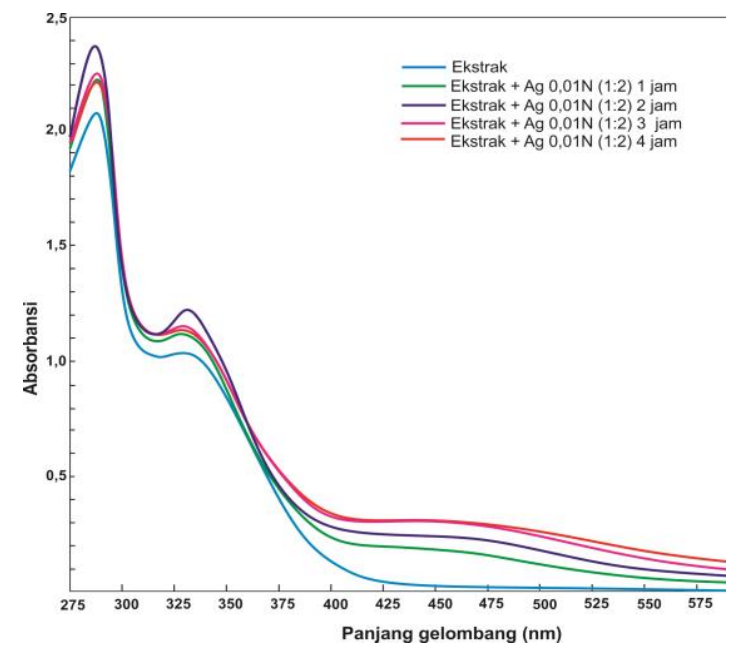

(b)

Gambar 2. Hasil UV-Vis nanopartikel perak 0.01 $\mathrm{N}$ (a) ekstrak: $\mathrm{AgNO}_{3} \quad 0.01 \quad \mathrm{~N} \quad 1: 1 \quad$ (v/v) (b) ekstrak: $\mathrm{AgNO}_{3} 0.01 \mathrm{~N}, 1: 2(\mathrm{v} / \mathrm{v})$
Pada hasil analisis UV-Vis gambar 2 terlihat nanopartikel perak mulai terbentuk pada waktu 2 jam untuk ekstrak: $\mathrm{AgNO}_{3} 0.01 \mathrm{~N}$ $1: 1$, sedangkan untuk ekstrak: $\mathrm{AgNO}_{3} 0.01 \mathrm{~N}$ 1:2 nano partikel perak terbentuk pada waktu 3 jam, ditandai dengan puncak serapan nanopartikel perak berada pada panjang gelombang 436-453 nm. Hal ini sesuai dengan penelitian sebelumnya oleh Obaid et al., (2015) yang memperoleh nanopartikel perak dengan SPR pada panjang gelombang 436-446 nm.

Hasil yang diperoleh dari pita serapan yang terbentuk dari ekstrak:larutan $\mathrm{AgNO}_{3}$ $0.01 \mathrm{~N}$ dengan perbandingan 1:1 lebih banyak dibandingkan dengan pita serapan yang terbentuk dari ekstrak:larutan $\mathrm{AgNO}_{3} 0.01 \mathrm{~N}$ dengan perbandingan 1:2. Sehingga untuk sintesis Ag-TCP, peneliti menggunakan campuran dengan perbandingan volume 1:1 untuk ekstrak daun alpukat dan $\mathrm{AgNO}_{3} 0.01 \mathrm{~N}$.

Dari hasil analisis spektroskopi UVVis juga terlihat, setelah waktu 3 jam, SPR dari nanopartikel perak bergeser ke panjang gelombang yang lebih besar. Hal ini disebabkan perubahan sifat optik dari nanopartikel perak ketika partikel teraglomerasi dan konduksi elektron yang mendekati permukaan partikel menjadi terdelokalisasi dan terbagi dengan partikel lain, sehingga SPR berpindah ke energi lebih rendah menyebabkan puncak serapan berpindah pada panjang gelombang yang lebih besar (Jenkins, 2000)

\section{Hasil Analisis X-Ray Diffraction (XRD)}

Analisis XRD dilakukan untuk mengetahui struktur dan ukuran kristal dari sampel yang diperoleh. Pada gambar 3 terlihat pola difraksi dari TCP yang diperoleh sesuai dengan pola difraksi dari TCP dengan ICD nomor 97500. Dengan demikian struktur yang dimiliki TCP hasil sintesis adalah rhombohedral. Hal ini sesuai dengan laporan penelitian sebelumnya dengan pola difraksi yang sama dinyatakan oleh Carrodeguas dan Aza (2011). Struktur TCP yang dihasilkan rhombohedral menyatakan bahwa TCP yang dihasilkan adalah $\beta$-TCP. Dari persamaan Scherer diperoleh ukuran kristal TCP sebesar $64 \mathrm{~nm}$

Analisis XRD untuk TCP-Ag 0,01 N terlihat pada gambar 3, terlihat puncak difraksi Ag dan TCP muncul bersamaan dimana puncak TCP masih memiliki pola difraksi yang 
sama dengan pola difraksi TCP tanpa nanopartikel perak. Puncak dari Ag yang terbentuk sesuai dengan puncak Ag pada ICD nomor 604631 yaitu pada $2 \theta: 38.26^{\circ}$; $44.49^{\circ}$; $64.57^{\circ}$ dan $77.52^{\circ}$ dengan struktur face centre cubic (fcc). Dari hasil XRD dapat dihitung nilai ukuran Kristal perak menggunakan persamaan Scherrer yaitu sebesar $46 \mathrm{~nm}$. Terlihat bahwa tidak terdapat perubahan pola difraksi dari TCP baik dalam keadaan murni maupun saat telah dicampurkan kedalam nanopartikel perak. Ini menandakan terbentuknya komposit TCP-Ag yang berinteraksi secara fisika.

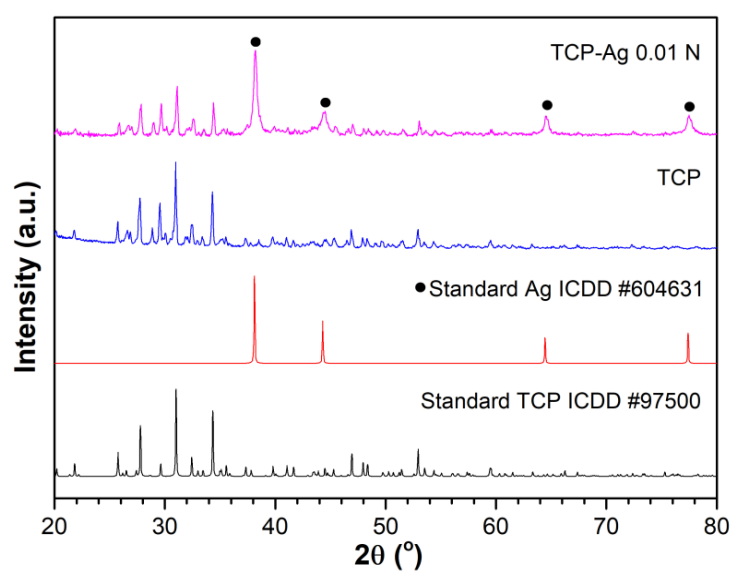

Gambar 3. Hasil XRD TCP dan TCP-Ag hasil sintesis.

\section{Hasil Scanning Electron Microscopy (SEM)}

Untuk analisa morfologi dan permukaan dari TCP, TCP-Ag yang dihasilkan dilakukan analisis SEM. Dari hasil SEM pada gambar 4 (a) terlihat bentuk partikel dari TCP hasil sintesis yang tidak bulat dan saling menyatu (teraglomerasi) dan didukung dari data XRD TCP bahwa masih ada puncakpuncak difraksi kecil yang bukan TCP, menandakan TCP hasil sintesis belum murni. Dari hasil SEM pada gambar 4.(b) terlihat partikel-partikel yang berwarna lebih gelap (ukuran lebih besar) dan partikel-partikel yang berwarna lebih terang (bintik-bintik putih). Hal ini disebabkan oleh sinyal elektron yang diberikan oleh alat SEM yaitu atom-atom dengan densitas atau berat molekul lebih besar akan memantulkan lebih banyak elektron sehingga tampak lebih cerah dari atom berdensitas rendah. Permukaan yang tinggi akan lebih banyak melepaskan elektron dan menghasilkan gambar yang lebih cerah dibandingkan permukaan yang rendah atau datar (Goldstein et al., 2003). Dengan demikian, bisa dikatakan bahwa partikel berukuran lebih besar (warna lebih gelap) adalah partikel TCP sementara partikel bintikbintik yang berwana lebih terang adalah partikel perak. Didukung oleh data XRD yang menyatakan ukuran Kristal TCP jauh lebih besar dari ukuran Kristal perak. Pada gambar 4.b juga terlihat partikel perak terdapat disetiap partikel-partikel TCP. Bisa dikatakan penyebaran partikel perak yang homogen.

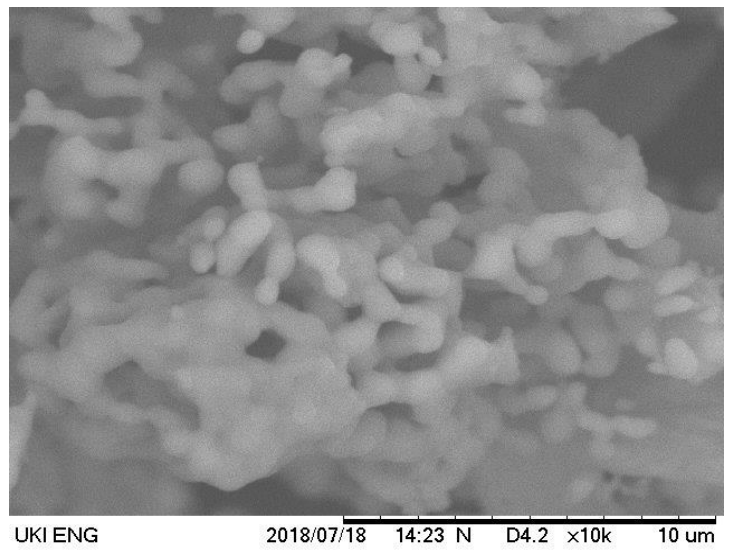

(a)

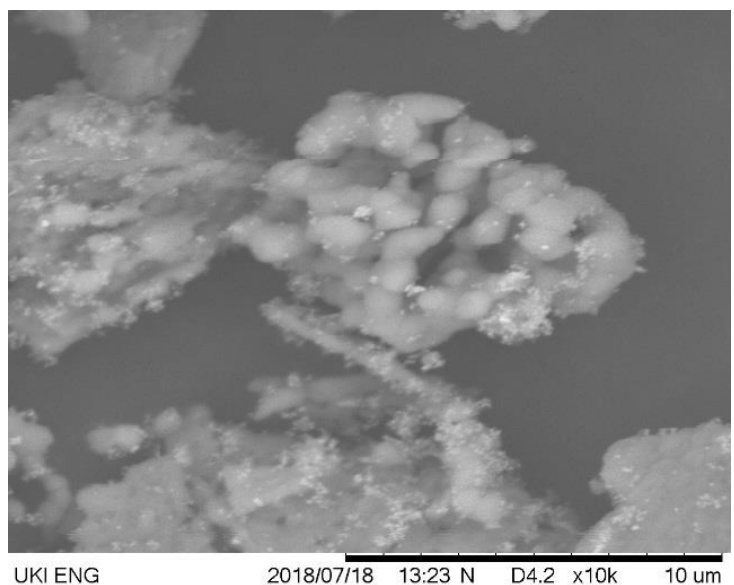

(b)

Gambar 4. Hasil SEM (a) TCP hasil sintesis (b) Ag-TCP hasil sintesis.

\section{SIMPULAN}

Dari hasil penelitian yang telah dilakukan, ekstrak daun alpukat dapat mereduksi larutan perak nitrat menghasilkan partikel perak yang ditandai dengan Surface Plasmon Resonance (SPR) pada panjang gelombang 445-446 $\mathrm{nm}$. Koloid perak yang 
terbentuk, ditambahkan dengan Tri Calcium Phosphate (TCP) sehingga terbentuklah komposit Ag-TCP. Pada pengukuran XRD diperoleh puncak TCP dan Ag yang sesuai dengan data ICD. Dengan menggunakan persamaan Scherrer diperoleh ukuran partikel TCP sebesar $64 \mathrm{~nm}$, Ag pada TCP-Ag $0.01 \mathrm{~N}$ sebesar $46 \mathrm{~nm}$. Dari gambar SEM terlihat bahwa sebaran partikel perak merata disekitar partikel TCP.

\section{UCAPAN TERIMA KASIH}

Pada kesempatan ini penulis mengucapkan terima kasih kepada Pusdiklat Kementerian Perindustrian RI yang telah memberikan dana bantuan penelitian.

\section{DAFTAR PUSTAKA}

Banerjee P, Satapathy M, Mukhopakayay A, Das P. 2014. Leaf extract mediated green synthesis of silver nanoparticle from widely available Indian plants: synthesis, characterization, antimicrobial property and toxicity analysis. Bioresources and Bioprocessing. 1(3): 1-10.

Brajendra S, Samayendra K. 2015. Phase stability of silver particles embedded calcium phosphate bioceramic. BullMater.Sci. 38(2): 525-529.

Carrodeguas RG, Aza SD. 2011. $\alpha$-tricalcium phosphate: synthesis, properties, and biomedical application. Acta Biomaterial. 7(2011): 3536-3546.

Chaair H, Labjar H, Britel O. 2017. Synthesis of $\beta$ tricalsium phosphate. Morphologie. 101(334): 120-124.

Goldstein J, Newbury D, Joy D, Lyman C, Echlin P, Lifshin E, Sawyer L, Michael J. 2003. Scanning Electron Microscopy and X-Ray Microanalysis'. $3^{\text {rd }}$ edition.

Gopinath V, Mubarak AD, Priyadarshini S, Priyadarhini NM, Thajuddin N, Velusamy P. 2012. Biosynthesis of silver nanoparticle from Tribulus terrestris and its antimicrobial activity: a novel biological approach. Colloid and Surface B: Biointerfaces. 96: 69-74.

Jami MS. 2017. Green Synthesis Nanokomposit Perak-Hidroksiapatit Menggunakan Bioreduktor Ekstrak Daun Gambir
(Uncaria gambir Roxb) dan uji aktivitas antibakteri. [Skripsi]. FMIPA Unand.

Jenkins R. 2000. X-Ray Technique: Overview (In Encyclopedia Of Analytical Chemistry). John Wiley \& Sons Ltd. Chichester.

Junaidi, Ahmad B, Wahyudi A. 2015. Kajian Sintesis Nanopartikel Perak pada Komposit Kitosan dan Polietilen Glikol: Efek Jenis Agen Pereduksi Organik. Banjarbaru(ID): Kimia FMIPA, Universitas Lambung Mangkurat. 5-7.

Kelly KL, Coronado E, Zhao LL, Schatz GC. 2003. The optical properties of metal nanoparticle: The influence of size, shape and dielectric environment. J. Phys. Chem. B. 107: 668-667.

Kumar B, Cumbal L. 2016. UV-Vis, FTIR and antioxidant study of Percea Americana (Avocado) leaf and fruit: a comparison. Revista de la Facultad de Ciencas Quimicas. 14: 13-20.

Navindra KP, Nas F, Athirah NA, Zaini MZ, Jamal H, Liew JP, Rajkumar D. 2014. Antibiofilm properties of chemically synthesized silver nanoparticle found against Pseudomonas aeruginosa. Journal of Nanobiotechnology. 12(2): 1-7.

Obaid AY, Al-Thabaiti SA, Alharbi LM, Khan Z. 2015. Extracellular bio-synthesis of silver nanoparticles. Global Advanced Research Journal of Microbiology. 3(8): 119-126.

Ozkan G, Takayuki N, Kyosuke U, Celaletdin E. 2015. Synthesis and characterization of Ag-containing calcium phosphates with various $\mathrm{Ca} / \mathrm{P}$ ratios. Material Science and Engineering C. 53: 111-119.

Sangiliyandi G, Jae WH, Deug-Nam K, Jin-Hoi K. 2014. Enhanced antibacterial and antibiofilm activities of silver nanoparticle against gram-negative and gram-positive bacteria. Nanoscale Research Lett. 9(1): 373.

Shital B. 2011. A biogenic approach for green synthesis of silver nanoparticle using extract of Foeniculum vulgare and its activity against Stapylococcus aureus and E. Coli. Bioscience. 3(2): 59-63.

Siavash I, Behzad Z. 2013. Green synthesis of silver nanoparticles using Pinus eldarica 
bark extract. Biomed Research Int. 2013: $1-5$.

Singh P, Katyal A, Kalra R, Chandra R. 2008. Copper nanoparticle in an ionic liquid : An efficient catalyst for the synthesis of bis(4-hydroxy-2-oxothiazolyl)methanes. Tetrahedron Lett. 49: 727-730.

Veerasamy R, Xin TZ, Gunasagaran S, Xiang TFW, Yang EFC, Jeyakumar N. 2011.
Biosynthesis of silver nanoparticles using Mangosteen leaf extraxt and evaluation of their antimicrobial activities. Journal of Saudi Chemical Society. 15: 113-120.

Vinay SP, Chandrashaker N, Chandrappa CP. 2017. Silver nanoparticles: synthesized by leaves extract of avocado and their antibacterial activity. International Journal of Engineering Develpoment and Research. 5(2): 1608-1613. 